\title{
ANALISIS KEMAMPUAN LITERASI MATEMATIKA MAHASISWA DALAM PROSES PEMBELAJARAN DI IAIN TAKENGON
}

\author{
Rosliana Harahap \\ IAIN Takengon \\ r05liana007@gmail.com
}

\begin{abstract}
Mathematical literacy is the capacity of individuals to formulate, use and interpret mathematics in various contexts. Mathematical literacy skills consist of 6 levels, level I, II, and III are low level thinking abilities while level IV, V and VI are high level thinking abilities. These levels can be measured using PISA questions, PISA questions are arranged with content, context and process. Mathematical literacy ability can develop human mindset so that it can find solutions to every problem. This research was conducted to determine the level of literacy ability of students in the first semester of TMA IAIN Takengon TA. 2019 / 2020. This study uses a quantitative description approach. population and sample of 11 students in semester I of TMA IAIN Takengon. The students will be given a math literacy ability test which will be calculated on average. The results of the 11 students' mathematical literacy ability test at level I have an average score of 68.18 so that the mathematics literacy ability of students is in the moderate category, at level II the average score of the student is 69.09 in the medium category, level III average score students are 67.72 in the medium category, the average level IV score of students is 51.81 in the low category, at level $\mathrm{V}$ the average score of students is 45 in the low category and at level VI the average score of students is 28.63 in the category low. And the score of 11 students' mathematical literacy ability is 55,076 in the low category. Because the overall mathematical literacy ability of students in the category is low so it must be done innovation and development of appropriate learning models so that students' mathematical literacy skills are even better.
\end{abstract}

Keywords: Literacy ability, Mathematics, PISA

\begin{abstract}
Abstrak: Kemampuan literasi matematika adalah kapasitas individu untuk memformulasikan, menggunakan, dan menafsirkan matematika dalam berbagai konteks. Kemampuan literasi matematika dapat mengembangkan pola pikir manusia sehingga dapat menemukan solusi dari setiap masalah. Penelitian ini dilakukan untuk mengetahui tingkat kemampuan literasi mahasiswa semester I TMA IAIN Takengon TA. 2019/2020. Penelitian ini menggunakan pendekatan deskripsi kuantitatif. Dengan populasi dan sampel seluruh mahasiswa semester I TMA IAIN Takengon yang berjumlah 11 orang. Mahasiswa akan diberikan tes kemampuan literasi matematika yang selanjutnya nilainya akan dihitung rata-ratanya. Hasil tes kemampuan literasi matematika 11 mahasiswa tersebut pada level I memilki rata-rata nilai 68,18 sehingga kemampuan literasi matematika mahasiswa dalam kategori sedang, pada level II rata-rata hasil tes kemampuan literasi matematika mahasiswa adalah 69,09 dalam katerogi sedang, pada level III nilai rata-rata hasil tes kemampuan literasi matematika mahasiswa adalah 67,72 dalam kategori sedang, pada level IV rata-rata nilai hasil tes kemampuan literasi matematika mahasiswa adalah 51,81 dalam kategori rendah, pada level V nilai rata-rata kemampuan literasi matematika mahasiswa adalah 45 dalam kategori rendah dan pada level VI rata-rata nilai kemampuan literasi matematika mahasiswa adalah 28,63 dalam kategori rendah. Dan nilai rata-rata kemampuan literasi matematis 11 mahasiswa tersebut adalah 55,076 dalam kategori rendah. Karena kemampuan literasi mahasiswa matematika dalam kategori rendah maka perlu dilakukan inovasi pembelajaran yang dapat meningkatkan kemampuan literasi matematika mereka.
\end{abstract}

Kata Kunci : Kemampuan literasi, Matematika, PISA

\section{PENDAHULUAN}

Pada zaman millennial ini dibutuhkan manuasia yang memiliki pengetahuan, keterampilan dan mampu menemukan inovasi baru, memiliki kompetensi etos kerja yang 
tinggi serta memilki etika dan moral yang baik. Manusia harus dapat memanfaatkan pengetahuannya secara optimal agar dapat menghadapi perubahan-perubahan di era millenial. Pengetahuan diperoleh dari proses pendidikan di sekolah, pengalaman di lingkungan dan dari lembanga pengembangan keterampilan. Pengetahuan dan keterampilan sangatlah penting agar masyarakat dapat menghadapi tuntutan kehidupan yang semakin beragam.

Menurut Rosalia (2015: 1) pendidikan memiliki peranan yang penting dalam menghadapi perubahan di zaman sekarang. Pendidikan menjadi alat untuk menghadapi tantangan dan menemukan ketentraman hidup, sehingga pendidikan saat ini harus disusun sesuai dengan kebutuhan pasar sehingga dapat menghasilkan manusia yang cerdas, kreatif, kritis, inovatif, fleksibel, memecahkan masalah, dan dapat melihat peluang sehingga dapat mencapai suksesan dalam pekerjaan maupun kehidupan sehari-hari. Oleh karena itu, pendidikan berperan penting untuk mengembangkan kemampuan-kemampuan tersebut pada diri manusia. Matematika adalah salah satu mata pelajaran dalam dunia pendidikan, dan merupakan mata pelajaran yang diperoleh siswa dari SD sampai dengan perguruan tingggi.

Matematika adalah ilmu dasar yang memiliki peranan penting dalam proses kehidupan manusia. Setiap hari kita melakukan kegiatan bermatematika, seperti kita belanja di warung, membayar listrik, dll. Matematika dianggap sebagai quen of knowledge, karena matematika digunakan dalam semua bidang ilmu, seperti biologi, kedokteran, ekonomi dan ilmu-limu sosial, melalui matematika lahirlah perkembangan teknologi modern. Sehingga matematika penting diajarkan dari tingkat sekolah dasar samapi perguruan tinggi karena melalui matematika diharapkan akan menghasilkan manuasia yang dapat menemukan solusi dari segala tantangan kehidupan. Matematika yang digunakan dalam segala segi kehidupan disebut literasi matematika.

Berdasarkan hasil survei yang dilakukan oleh Programme for International Student Assessment (PISA) anak Indonesia di PISA belum ada yang mencapai level tertinggi 6. Anak Indonesia di PISA yang tidak mencapai level 2 sebanyak 76\%, dan jumlah anak yang mencapai level tertinggi 5 hanya 0,3\%. Pada tahun 2015, Indonesia masuk dalam 10 negara dengan kemampuan literasi rendah berada di posisi 69 dari 72 negara dengan rata-rata skor literasi matematika siswa 386 di bawah skor rata-rata negara OECD yaitu 490 dan masih termasuk dalam level 1 (OECD, 2016). Dari hasil PISA tersebut diketahui bahwa level kemampuan literasi matematika siswa di Indonesia berada 
pada level 1. Karena kemampuan literasi matematika rendah, maka kemampuan literasi matematika siswa perlu dilatih, dengan cara membiasakan soal PISA dalam proses belajar dan mengajar.

Berdasarkan uraian di atas maka kemampuan literasi matematika harus ditingkatkan sehingga siswa memiliki kemampuan penalaran, koneksi, pemecahan masalah, generalisasi dan kreatif . Kemampuan-kemampuan tersebut dapat berkembang sejalan dengan kemampuan literasi matematika. Kemampuan literasi matematika sangat diperlukan agar pola pikir seseorang dapat berkembang secara logis, rasional, kreatif, inovatif dan dapat menemukan solusi dari sebuah masalah, oleh sebab itu seluruh mahasiswa dan khususnya mahasiswa tadris matematika IAIN Takengon harus memilki keterampilan literasi matematika secara baik. Jika kemampuan literasi matematis mahasiswa semester I TA. 2019/2020 tadris matematika IAIN Takengon masih kurang maka perlu suatu tindakan agar kemampuan literasi matematika mereka menjadi baik. Atas dasar itu perlu dilakukan penelitian untuk mengukur kemampuan matematik mahasiswa tadris matematika IAIN Takengon yang berjumlah 11 mahasiswa di semester satu TA. 2019/2020.

\section{LANDASAN TEORI}

\section{Kemampuan Literasi Matematis}

Mulyono Abdurahman (2003 : 252) mengemukakan bahwa matematika adalah suatu cara untuk menemukan jawaban terhadap masalah yang dihadapi manusia, suatu cara menggunakan informasi, menggunakan pengetahuan tentang bentuk dan ukuran, menggunakan pengetahuan tentang menghitung, dan yang paling penting adalah memikirkan dalam diri manusia itu sendiri dalam melihat dan menggunakan hubunganhubungan yang ada. Menurut Moll (1994) literasi menunjukkan kemampuan membaca, menulis, berbicara dan menggunakan bahasa. Literasi bukan pengetahuan yang terisolasi tetapi perkembangan kemampuan siswa dalam menggunakan bahasa dan tulisan dalam kegiatan yang lebih luas.

Dalam PISA literasi matematika diartikan sebagai kapasitas individu untuk memformulasikan, menggunakan, dan menafsirkan matematika dalam berbagai konteks. yaitu penalaran matematika, penggunaan konsep, prosedur, fakta, mendeskripsikan, menjelaskan dan mempresentasikan fenomena. Hal ini menuntun individu untuk mengenali peranan matematika dalam kehidupan dan membuat penilaian yang baik dan 
pengambilan keputusan yang dibentuk oleh penduduk yang kontruktif dan reflektif (OECD, 2012). Tiga komponen besar yang diidentifikasikan dalam studi PISA (OECD, 2010) yaitu komponen konten, proses dan konteks. sehingga kemampuan Literasi matematika adalah kemampuan siswa untuk mengaplikasikan pengetahuan yang diperoleh dari sekolah maupun di luar sekolah untuk menyelesaikan masalah-masalah yang muncul. Penjelasan tiga komponen literasi matematika ada pada gambar di bawah ini.

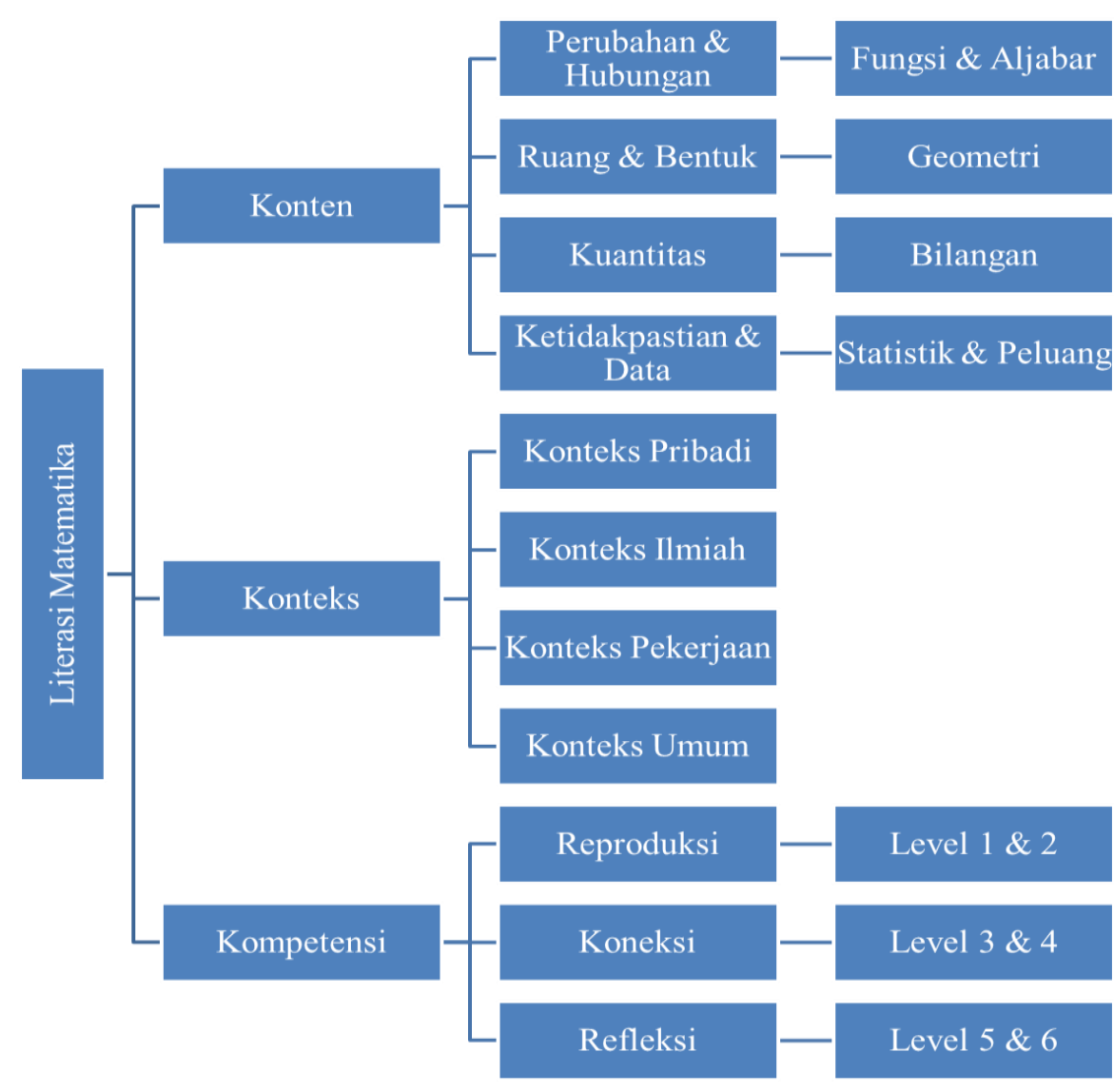

Gambar 1. Tiga komponen mayor dari domain matematika

Dengan melihat gambar di atas maka literasi matematika terdiri dari konten, konteks dan kompetensi. Pada kompetensi terdapat tiga aktifitas yaitu reproduksi yaitu kemampuan siswa menggunakan matematika pada masalah yang sederhana, koneksi yaitu kemampuan siswa untuk menguhungkan matematika dengan konteks lainnya, dan refleksi yaitu kemampuan siswa untuk menyelesaikan masalah matematika yang tidak terstruktur. Selanjutnya kemampuan literasi matematika menurut Rahmah Johar (2012) adalah sebagai berikut. 
Tabel 1. Kemampuan literasi matematika pada PISA

Level

Kompetensi Matematika

1 Siswa dapat menjawab pertanyaan yang konteksnya umum, pada level ini soal merupakan masalah rutin yang sederhana

2 Siswa dapat memilah informasi yang relevan, menggunakan rumus, dapat memberikan alasan secara langsung dan melakukan penafsiran harafiah.

3 Siswa dapat memilih dan menerapkan strategi memecahkan masalah yang sederhana.

4 Siswa dapat bekerja secara efektif dengan model dalam situasi yang konkret tetapi kompleks.

5 Siswa dapat bekerja dengan model, dan melakukan dugaan-dugaan, membandingkan, dan mengevaluasi strategi untuk memecahkan masalah yang rumit yang berhubungan dengan model ini.

6 Siswa dapat melakukan konseptualisasi dan generalisasi dengan menggunakan informasi berdasarkan modelling dan penelaahan dalam suatu situasi yang kompleks.

Di dalam literasi matematika mengacu kepada indikator, terdapat sebuah model praktek dari pengaplikasian soal PISA yang dikemukakan oleh OECD. PISA tidak hanya sekedar membuat model atau representasi matematis dari suatu permasalahan nyata tetapi sebaliknya sehingga kemampuan bernalar dan pemecahan masalah sangat diperlukan. Melalui proses ini kemampuan bernalar akan terus diasah begitu juga dengan kemampuan lainya. Menurut Ice Afriyanti (2018: 610) tahapan-tahapan dari proses matematisasi yang ada pada PISA 2013 meliputi merumuskan, menggunakan, menafsirkan dan mengevaluasi yang digambarkan pada bangan di bawah ini:

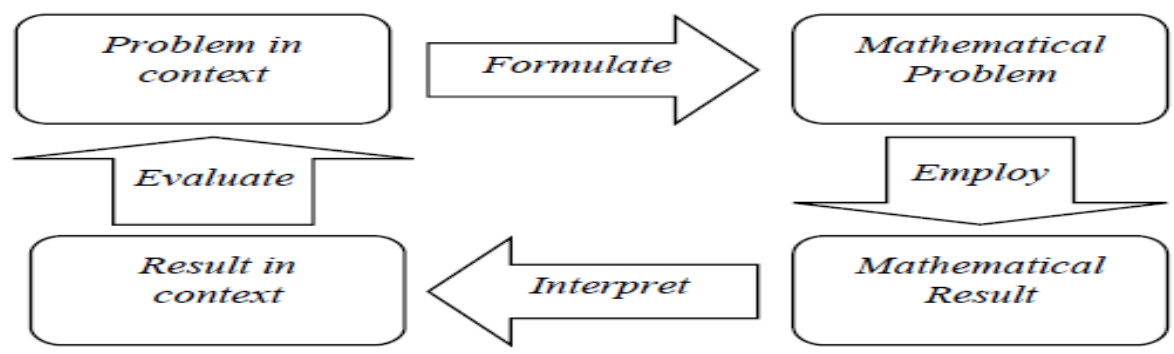

Gambar 2. Model praktek literasi matematika (OECD, 2013) 


\section{METODE PENELITIAN}

Penelitian ini menggunakan pendekatan diskripsi kuantitatif, penelitian bertujuan menjelaskan fenomena yang ada dengan menggunakan angka-angka untuk menggambarkan karakteristik induvidu atau kelompok. Yang menjadi subjek adalah populasi mahasiswa semester I TMA IAIN Takengon TA. 2019/2020 yang berjumlah 11 orang. Instrumen penelitian ini adalah tes pilihan berganda dan uraian, yaitu tes kemampuan literasi matematika tipe PISA. Sebelum tes diberikan kepada siswa tes tersebut telah dilakukan uji validitas. Validasi dilakukan oleh tim ahli dan ujicoba ke mahasiswa. Setelah tes memenuhi standar kevalidannya maka tes diberikan kepada mahasiswa. Mahasiswa diberikan batasan waktu dalam mengerjakan tes, setelah batas waktu habis jawaban mahasiswa dikumpulkan untk diperiksa dan dianalisis serta dideskripsikan.

Data dalam penelitian ini adalah data kuantitatif yang diperoleh melalui skor tes kemampuan literasi matematika. Skor dari jawaban mahasiswa tersebut dianalisis secara deskriptif untuk menggambarkan kemampuan literasi matematika mahasiswa. Setiap langkah dalam penyelesaian tes memiliki bobot nilai sendiri. Jika tidak dijawab skornya nol, jika menjawab tetapi belum benar skornya satu, jika menjawab tetapi belum sempurna skornya tiga dan jika menjawab benar dan sempurna skornya empat. Nilai kemampuan literasi matematika siswa diperoleh dengan menggunakan rumus:

$$
X=\frac{S P S}{S M I} \times 100
$$

Keterangan:

$\mathrm{X}=$ Nilai kemampuan literasi matematika siswa

SPS $=$ Skor Perolehan Siswa

SMI = Skor Maksimal Ideal

Jika mahasiswa memperoleh Nilai $X \geq 80$, maka mahasiwa memiliki kemampuan literasi matematika yang "tinggi”, apabila mahasiswa memperoleh Nilai $60<\mathrm{X} \leq 80$, maka mahasiswa memiliki kemampuan literasi matematika "sedang" dan apabila mahasiswa memperoleh Nilai $\mathrm{X}<60$, maka mahasiswa dikatakan memiliki kemampuan literasi matematika "rendah". 


\section{HASIL DAN PEMBAHASAN}

\section{Hasil Penelitian}

Menurut (Wledarti, dkk., 2016: 7) literasi dapat diartikan sebagai kemampuan siswa untuk membaca tidak hanya buku teks, namun berbagai fenomena dalam kehidupan sehari-hari sebagai lingkungan belajar secara analitis, kritis dan reflektif. Sedangkan literasi matematika menurut Isnaini dalam (Maryanti, 2012:16) adalah kemampuan peserta didik untuk dapat mengerti fakta, konsep, prinsip, operasi, dan pemecahan masalah matematika. Karena pentingnya kemampuan literasi matematika seseorang sehingga dilakukanlah penelitian ini. Adapun hasil yang diperoleh dari penelitian ini sebagai berikut.

Hasil penelitian ini berupa diskripsi kemampuan literasi matematika mahasiswa tadris matematika (TMA) IAIN Takengon TA. 2019/2020. Data ini diperoleh dari nilai skor tes kemampuan literasi matematika yang diberikan kepada 11 mahasiswa. Jawaban 11 orang mahasiswa didiskripsikan sehingga kita mampu mengetahui kemampuan masing-masing mahasiswa terrhadap kemampuan literasi matematika. Kemampuan literasi matematika terdiri dari 6 level. Adapun skor mahasiswa setiap level disajikan sebagai berikut:

Tabel 2. Hasil tes kemampuan literasi matematika mahasiswa

\begin{tabular}{|c|c|c|c|c|c|c|c|c|}
\hline \multirow[t]{2}{*}{ No } & \multirow[t]{2}{*}{ Mahasiswa } & \multicolumn{6}{|c|}{ Nilai kemampuan literasi matematika per level } & \multirow[t]{2}{*}{ Rata-rata } \\
\hline & & $\mathbf{I}$ & II & III & IV & $\mathbf{V}$ & VI & \\
\hline 1 & $\mathrm{AB}$ & 70 & 65 & 70 & 40 & 30 & 0 & 45.83333 \\
\hline 2 & $\mathrm{AC}$ & 85 & 85 & 75 & 50 & 50 & 30 & 62.5 \\
\hline 3 & $\mathrm{AD}$ & 45 & 60 & 70 & 35 & 40 & 25 & 45.83333 \\
\hline 4 & $\mathrm{AE}$ & 90 & 95 & 85 & 85 & 70 & 60 & 80.83333 \\
\hline 5 & $\mathrm{AF}$ & 50 & 45 & 45 & 30 & 0 & 0 & 28.33333 \\
\hline 6 & $\mathrm{AG}$ & 40 & 20 & 10 & 0 & 0 & 0 & 11.66667 \\
\hline 7 & $\mathrm{AH}$ & 100 & 95 & 95 & 85 & 85 & 75 & 89.16667 \\
\hline 8 & $\mathrm{AI}$ & 50 & 60 & 40 & 30 & 30 & 10 & 36.66667 \\
\hline 9 & $\mathrm{AJ}$ & 50 & 70 & 70 & 50 & 45 & 45 & 55 \\
\hline 10 & $\mathrm{AK}$ & 90 & 90 & 100 & 85 & 70 & 70 & 84.16667 \\
\hline \multirow[t]{2}{*}{11} & $\mathrm{AL}$ & 80 & 75 & 85 & 80 & 75 & 0 & 65.83333 \\
\hline & & 68.181 & 69.00 & 67.727 & 51.818 & 45 & 28.636 & 55,076 \\
\hline
\end{tabular}

Dari tabel di atas kemampuan literasi matematika 11 mahasiswa tersebut pada level I memilki rata-rata nilai 68,18 sehingga kemampuan literasi matematika mahasiswa dalam kategori sedang, pada level II rata-rata skor kemampuan literasi matematika mahasiswa adalah 69,09 dalam katerogi sedang, level III rata-rata skor tes 
kemampuan literasi matematika mahasiswa adalah 67,72 dalam kategori sedang, pada level IV rata-rata nilai hasil tes kemampuan literasi matematika mahasiswa adalah 51,81 dalam kategori rendah, pada level $\mathrm{V}$ nilai rata-rata kemampuan literasi matematika mahasiswa adalah 45 dalam kategori rendah dan pada level VI rata-rata nilai kemampuan literasi matematika mahasiswa adalah 28,63 dalam kategori rendah. Dan nilai rata-rata kemampuan literasi matematis 11 mahasiswa tersebut adalah 55,076 dalam kategori rendah.

Sedangkan kemampuan literasi mahasiswa perinduvidu sangat beragam. Mahasiswa AB pada level I tes kemampuan literasi matematika memperoleh nilai 70, level II memperoleh nilai 65, level III memperoleh 70, level IV memperoleh 40, level V memperoleh 30 dan level VI memperoleh nilai 0, nilai rata-rata dari seluruh level adalah 45,83 sehingga kemampuan literasi matematika mahasiswa $\mathrm{AB}$ dalam kategori rendah.

Mahasiswa AC pada level I tes kemampuan literasi matematika memperoleh nilai 85, level II memperoleh nilai 85, level III memperoleh 75, level IV memperoleh 50, level V memperoleh 50 dan level VI memperoleh nilai 30, nilai rata-rata dari seluruh level adalah 62,5 sehingga kemampuan literasi matematika mahasiswa AC dalam kategori sedang.

Mahasiswa AD pada level I tes kemampuan literasi matematika memperoleh nilai 45, level II memperoleh nilai 60, level III memperoleh 70, level IV memperoleh 35, level V memperoleh 40 dan level VI memperoleh nilai 25, nilai rata-rata dari seluruh level adalah 45,83 sehingga kemampuan literasi matematika mahasiswa AD dalam kategori rendah.

Mahasiswa AE pada level I tes kemampuan literasi matematika memperoleh nilai 90, level II memperoleh nilai 95, level III memperoleh 85, level IV memperoleh 85, level V memperoleh 70 dan level VI memperoleh nilai 60, nilai rata-rata dari seluruh level adalah 80,83 sehingga kemampuan literasi matematika mahasiswa AE dalam kategori tinggi.

Mahasiswa AF pada level I tes kemampuan literasi matematika memperoleh nilai 50, level II memperoleh nilai 45, level III memperoleh 45, level IV memperoleh 30, level V memperoleh 0 dan level VI memperoleh nilai 0 , nilai rata-rata dari seluruh level adalah 28,33 sehingga kemampuan literasi matematika mahasiswa AF dalam kategori rendah. 
Mahasiswa AG pada level I tes kemampuan literasi matematika memperoleh nilai 40, level II memperoleh nilai 20, level III memperoleh 10, level IV memperoleh 0, level $\mathrm{V}$ memperoleh 0 dan level VI memperoleh nilai 0 , nilai rata-rata dari seluruh level adalah 11,67 sehingga kemampuan literasi matematika mahasiswa AG dalam kategori rendah.

Mahasiswa AH pada level I tes kemampuan literasi matematika memperoleh nilai 50, level II memperoleh nilai 60, level III memperoleh 40, level IV memperoleh 85, level V memperoleh 85 dan level VI memperoleh nilai 75, nilai rata-rata dari seluruh level adalah 89,17 sehingga kemampuan literasi matematika mahasiswa AH dalam kategori tinggi.

Mahasiswa AI pada level I tes kemampuan literasi matematika memperoleh nilai 45, level II memperoleh nilai 60, level III memperoleh 40, level IV memperoleh 30, level V memperoleh 10 dan level VI memperoleh nilai 10, nilai rata-rata dari seluruh level adalah 36,67 sehingga kemampuan literasi matematika mahasiswa AI dalam kategori rendah.

Mahasiswa AJ pada level I tes kemampuan literasi matematika memperoleh nilai 50, level II memperoleh nilai 70, level III memperoleh 70, level IV memperoleh 50, level V memperoleh 45 dan level VI memperoleh nilai 45, nilai rata-rata dari seluruh level adalah 55 sehingga kemampuan literasi matematika mahasiswa AJ dalam kategori rendah.

Mahasiswa AK pada level I tes kemampuan literasi matematika memperoleh nilai 90, level II memperoleh nilai 90, level III memperoleh 100, level IV memperoleh 85, level V memperoleh 70 dan level VI memperoleh nilai 70, nilai rata-rata dari seluruh level adalah 84,17 sehingga kemampuan literasi matematika mahasiswa AD dalam kategori tinggi.

Mahasiswa AL pada level I tes kemampuan literasi matematika memperoleh nilai 80, level II memperoleh nilai 75, level III memperoleh 85, level IV memperoleh 80, level V memperoleh 75 dan level VI memperoleh nilai 0, nilai rata-rata dari seluruh level adalah 65,83 sehingga kemampuan literasi matematika mahasiswa AD dalam kategori rendah.

\section{Pembahasan}

Dari hasil skor rata-rata tes kemampuan literasi matematika kemampuan mahasiswa masih rendah. Sebanyak 6 siswa memiliki kemampuan literasi matematika dalam 
kategori rendah, 2 orang dalam kategori sedang dan 3 orang dalam kategori tinggi. Secara keseluruhan rata-rata skor 11 mahasiswa masih kurang dari 60. Pada leve; I, II dan III mahasiswa memperoleh skor rata-rata lebih besar dari 60 tetapi kurang dari 70. Untuk level IV, V dan VI skor rata-rata mahasiswa masih kurang dari 60. Hanya ada 3 siswa saja yang mampu mencapai rata-rata skor lebih dari 60 untuk semua level pada soal tersebut..

Pada level I soal merupakan soal yang rutin dan konteksnya umum, sehingga ratarata mahasiswa dapat menyelesaikannya dengan benar. Pada level II, untuk menyelesaiakan soal dengan baik mahasiswa harus dapat menghubungkan rumus dengan informasi dari soal. Pada level III, mahasiswa harus dapat mengetahui prosedur dan memilih strategi yang tepat agar dapat menyelesaian tes dengan benar. Pada level IV, mahasiswa harus dapat menemukan model matematika dan menghubungkannya ke dalam dunia nyata. Pada level V, mahasiswa harus dapat menggunakan model yang kompleks sehingga dapat menyelesaikan masalah yang sulit. Dan level VI, mahasiswa harus menggunakan penalarannya sehingga dapat menemukan generalisasi, merumuskan dan mengkomunikasikan tes. Level V dan VI merupakan kemampuan berpikir tingkat tinggi sehingga banyak mahasiswa yang tidak mampu menyelesaikan tes level tersebut. Sedangkan level I dan Level II dan III merupakan tes untuk kemampuan berpikir tingkat rendah, dan level IV, V dan VI merupakan kemampuan berpikir tingkat tinggi.

Dari hasil penelitian ini terlihat bahwa kemampuan literasi matematika mahasiswa berada pada level I dan level II yaitu kompetensi koneksi dan berada pada tingkatan berpikir tingkat rendah. Mahasiswa hanya mampu menyelesaikan tes yang sederhana dan merupakan soal rutin saja. Sehingga pada tahapan penyelesaian soal PISA level 1 dan 2 rata-rata mahasiswa dapat menjawabnya dengan baik. pada Level 3 dan 4 ini, mahasiswa memiliki kesulitan dalam memahami soal, sehingga siswa tidak bisa merumuskan permasalahan kedalam bentuk model matematika. Pada level 5 dan level 6 mahasiswa tidak dapat menghubungkan soal dengan rumus, melakukan dugaan secara nalar dan mengevaluasi soal.

Adapun contoh soal pada level 5 yaitu “ Dalam perayaan HUT kota takengon pemerintah kota menyiapkan hiburan untuk masyarakat, adapun hiburannya berupa konser music yang diadakan di sebuah lapangan berbentuk persegi berukuran 100m x 100m, jika lapangan dipenuhi oleh penonton, dan penonto berdiri dan sedikit yang duduk. 
Berapakah kira-kira penoton konser tersebut? Apakah 10.000 orang, 40.000 orang atau . 100.000 orang?"

Untuk menyelesaikan soal di atas mahasiswa harusnya menghitung luas persegi terlebih dahulu, luas persegi adalah $\mathrm{s} \times \mathrm{s}=100 \mathrm{~m} \times 100 \mathrm{~m}=10.000 \mathrm{~m}^{2}$. Pada umumnya mahasiswa hanya menjawab samapai di sini saja, mereka bingung menyelesaikannya. Seharusnya mahasiswa bias mencari jawaban yang paling mungkin dari ketiga pilihan tersebut. Untuk jawaban 10.000 orang tidak mungkin karena informasi soal penonton memenuhi lapangan dengan posisi berdiri dan sedikit yang duduk, artinya jika 10.000 orang 1 orang menempati $1 \mathrm{~m}^{2}$ tidak masuk akal. Untuk jawaban 20.000 orang, artinya 40.000:10.000 = 4 artinya dalam $1 \mathrm{~m}^{2}$ ditempati oleh 4 orang, masuk akal. Untuk jawaban 100.000 orang, artinya 100.000:10.000 = 10 maka dalam $1 \mathrm{~m}^{2}$ ditempati oleh 10 orang, jawaban ini tidak masuk akal karena terlalu banyak penoton dalam $1 \mathrm{~m}^{2}$ sehingga jawaban yang paling masuk akal adalah 40.000 penonton. Dalam menyelasikan soal tersebut mahasiswa harus dapat membayangkan situasi yang kompleks mengkaitkan rumus dan bernalar.

Untuk soal PISA pada level 5 dan 6 memerlukan kemampuan berpikir tingkat tinggi, diperlunakan penalaran yang baik. Kesulitan mahasiswa adalah mengidentifikasikan masalah nyata ke dalam bentuk matematika, kesulitan dalam menentukan prosedur pengerjaan soal, kesulitan dalam memilih strategi yang tepat, kesulitan dalam melakukan dugaan penyelesaian dan membuat kesimpulan. Hal ini disebabkan penalaran mahasiswa yang kurang baik dan pemahaman materi yang belum maksimal sehingga mahasiswa kesulitan dalam menghubungkan masalah sehari-hari ke dalam model matematika dan menentukan strategi penyelesaiannya.

\section{KESIMPULAN DAN SARAN}

\section{Kesimpulan}

Kemampuan literasi matematika mahasiswa tadris matematika semester I IAIN Takengon TA. 2019/2020 masih dalam kategori rendah. Untuk masing-masing level sebagai berikut:

a. level I memilki rata-rata skor 68,18 sehingga kemampuan literasi matematika mahasiswa dalam kategori sedang,

b. level II rata-rata skor kemampuan literasi matematika mahasiswa adalah 69,09 dalam katerogi sedang, 
c. level III nilai rata-rata skor kemampuan literasi matematika mahasiswa adalah 67,72 dalam kategori sedang,

d. level IV rata-rata skor tes kemampuan literasi matematika mahasiswa adalah 51,81 dalam kategori rendah,

e. level V rata-rata skor kemampuan literasi matematika mahasiswa adalah 45 dalam kategori rendah

f. level VI rata-rata skor kemampuan literasi matematika mahasiswa adalah 28,63 dalam kategori rendah.

\section{Saran}

Guru / Dosen

Guru/dosen khususnya guru mata pelajaran matematika dan dosen matematika mau melakukan inovasi pembelajaran, baik itu pengembangan soal PISA, maupun pengembangan model pembelajaran. Sehingga dapat meningkatkan kemampuan lieterasi matematika. Guru dapat membuat forum diskusi sesama teman atau guru/dosen dalam mengembangkan soal PISA dari setiap materi matematika, semakin banyak soal maka semakin banyak siswa dapat melatih kemampuan literasi matematika, melalui kegiatan ini diharapkan kemampuan literasi mereka dapat meningkat. Karena kemampuan literasi matematika sangat penting untuk perkembangan pola pikir mahasiswa dan menjadi bekal mereka setelah menjadi sarjana kelak.

Siswa/mahasiswa

Diharapkan siswa/mahasiswa lebih memotivasi diri untuk belajar, melatih diri mengerjakan soal PISA. Mahasiswa/ siswa harus tetap semangat dalam menyelesaikan soal PISA walaupun mengalami kesulitan, karena soal PISA dapat melatih penalaran dan kreativitas seseorang.

\section{DAFTAR PUSTAKA}

Abdurrahman, Mulyono. (2003). Pendidikan bagi Anak Berkesulitan Belajar. Jakarta: Rineka Cipta Maryanti. Press.

Arikunto, Suharsimi. (2012). Prosedur Penelitian. Jakarta: Rineka Cipta.

Ice, Afriyanti,dkk. (2018). Pengembangan Literasi Matematika Mengacu PISA Melalui Pembelajaran Abad-21 Berbasis Teknologi PRISMA. Prosiding Seminar Nasional Matematika, 1, 608-617.

https://journal.unnes.ac.id 
Kadir. (2010). Penerapan Pembelajaran Kontekstual Berbasis Potensi Pesisir sebagai Upaya Peningkatan Kemampuan Pemecahan masalah Matematik, Komunikasi Matematik, dan Keterampilan Sosial Siswa SMP. Disertasi. Bandung: SPs UPI Bandung.

Linggar, Galih Mahanani, budi murtiyasa. (2016). Kemampuan Pemecahan Masalah Matematika Aljabar Berbasis TIMSS Pada Siswa SMP Kelas VII. Prosiding SEMPOA. 2, 1-9. http://hdl.handle.net/11617/7594

Maryanti. (2012). Peningkatan Literasi Matematis Peserta didik Melalui Pendekatan Metacognitive Guidance. Tesis. Bandung: UPI.

Moll, L. C. (1994). Vygotsky and Education: Instructional Implications and Applications of Sociohistorycal Psychology. Cambridge: University Press.

OECD, PISA. (2012). Assesment and Analytical Framework: Mathematics, Raeding, Science, Problem Solving and Financial Literacy. Paris: OECD Publisher.

OECD, PISA. (2013). Assesment and Analytical Framework: Mathematics, Raeding, Science, Problem Solving and Financial Literacy. Paris: OECD Publisher.

OECD, PISA. (2016). Assesment and Analytical Framework: Mathematics, Raeding, Science, Problem Solving and Financial Literacy. Paris: OECD Publisher.

Rahmah, Johar. (2012). Domain Soal PISA untuk Literasi Matematika. Jurnal Peluang, $1(1), 30-41$. http://jurnal.unsyiah.ac.id/peluang.

Rosalia, Hera, Novita Sari. (2015). Literasi Matematika: Apa, Mengapa, dan Bagaimana ?. Jurnal Seminar Matematika dan Pendidikan Matematika. 1(1), 713-720. http://Seminar.uny.ac.id.

Wledarti, dkk. (2016). Desain Induk Gerakan Literasi Sekolah. Jakarta: Kemdikbud. 